\title{
THE EFFECT OF ENTREPRENEURIAL BEHAVIOR ON SALTED FISH BUSINESS PERFORMANCE AT MUARA ANGKE
}

\author{
Nurfiqayumi Arnis*)1, Lukman M Baga*), and Burhanuddin*) \\ *) Magister of Sains Agribussines, Department of Agribussines, Faculty of Economic and Management, \\ Bogor Agricultural University \\ IPB Campus Dramaga, Kamper Road, Wing 4 Level 5 Dramaga, Bogor, Indonesia 16680
}

\begin{abstract}
Business performance was one of the benchmarks of entrepreneurial behavior so the concept of entrepreneurial behavior in businessmen is important, because it will impact on business performance. Entrepreneurial behavior is formed by two factors namely individual and environmental factors. The objective of this research were to analyze the effect of individual and environmental factors that influence entrepreneurial behavior and to analyze the influence of entrepreneurial behavior on business performance of Salted fish in Muara Angke. This research used Structural Equation Modeling-Partial Least Square (SEM-PLS) 3.0 for quantitative analysis. The result of this research indicated that individual factor had a positive effect and it was significant on entrepreneurial behavior with coefficient value 0.317 and t-statistics 3.860, while the environmental factor in salted fish business had a positive effect, and it was insignificant on entrepreneurial behavior because the value of t-statistics was $1,262<1.96$. Entrepreneurial behavior had a positive effect and it was significant on business performance. This can be seen from the t-statistic value of $2.551>1.96$, which means that any increase of entrepreneurial behavior will improve business performance of salted fish businessmen in Muara Angke.
\end{abstract}

Keywords: entrepreneurial behavior, business performance, salted fish, partial least square

\begin{abstract}
Abstrak: Kinerja usaha merupakan salah satu tolak ukur dari perilaku kewirausahaan sehingga adanya konsep perilaku kewirausahaan pada pelaku usaha merupakan hal yang penting, karena akan berdampak pada kinerja usaha. Perilaku kewirausahaan dibentuk oleh dua faktor, yakni faktor individu dan lingkungan. Tujuan penelitian ini adalah menganalisis pengaruh faktor individu dan lingkungan yang mempengaruhi perilaku kewirausahaan dan menganalisis pengaruh perilaku kewirausahaan terhadap kinerja usaha ikan asin di Muara Angke. Penelitian ini menggunakan alat analisis Structural Equation Modelling-Partial Least Square (SEM-PLS) 3.0 untuk analisis kuantitatif. Hasil penelitian ini menunjukkan faktor individu berpengaruh positif dan signifikan terhadap perilaku kewirausahaan dengan nilai koefisien, yaitu sebesar 0,317 dan nilai t-statistik sebesar 3,860. Sedangkan faktor lingkungan pada usaha ikan asin berpengaruh positif dan tidak signifikan terhadap perilaku kewirausahaan karena nilai t-statistik 1,262 < 1,96. Perilaku kewirausahaan berpengaruh positif dan signifikan terhadap kinerja usaha. Hal ini dilihat dari nilai t-statistik 2,551 > 1,96, artinya setiap peningkatan perilaku kewirausahaan akan meningkatkan kinerja usaha pelaku usaha ikan asin di Muara Angke.
\end{abstract}

Kata kunci: perilaku kewirausahaan, kinerja usaha, ikan asin, partial least square

\footnotetext{
${ }^{1}$ Corresponding author:

Email: nurfiqayumiarnis@gmail.com
} 


\section{INTRODUCTION}

In Indonesia, SMEs dominated most business sectors, especially in agriculture, fishery and livestock. Indonesia as the country's largest maritime axis and archipelago is endowed with a wealth of fishery resources that are very abundant and spread in almost all regions. The wealth of fishery resources which are cheap and provide useful protein than meat and chicken with high Omega 3 content and serve to improve human intelligence can be seen from the potential amount of sustainable fishery resources of 6.4 million tons and marine aquaculture and ponds covering 17.7 million hectares (Kementerian Kelautan dan Perikanan, 2013). The presence of SMEs could be a trigger for people to always think toward entrepreneurial business. The existence of entrepreneurial traits within a person capable of exploring the individual leads to the utilization of opportunities. The importance of entrepreneurship is also shown by Chang et al. (2009) who states that the British government publishes its national white book entitled "Our Competitive Future: Building the Knowledge Driven Economy 1999". It contains the reasons why entrepreneurship is so important and the information that entrepreneurship and innovation are critical incentives for the economic growth and development, since both can increase productivity and employment. Thus, it is very important to develop entrepreneurship as it can be a measure of the progress of a country. The more entrepreneurial attitudes that grow in the society, the higher the economic improvement of a country will be.

The increase of SMEs in Indonesia is followed by the potential of its resources. It could be seen from the vast sea and the number of large islands that made Indonesia a great potential of marine resources. In line with that, the development of fishery sector should be oriented to productivity increase, value-added and expansion of business opportunity of fishery sector (Tajerin and Sastrawidjaja, 2010).

DKI Jakarta is one of the locations in which fishing industry grows significantlly in Indonesia. The amount of fish catch in Jakarta indicated that fish business opportunities were large. The catch fish in Jakarta is more dominated by North Jakarta, which means that the fish production amount is a business opportunity to the fish processing in North Jakarta and the excess of the catch fish is not wasted. Catch fish SMEs was one of agroindustries engaged in fishery that produce salted fish consumed by Indonesians. This is because salted fish is one source of animal protein that has economic value and it can be stored for a long time. It also has high calcium content because low water content, its distinctive taste and aroma that does not change even if it is stored a long time and the price of it is more affordable than other fish products. Thus, salted fish become one of the fish processed products that much favored by the community in all layers. Various types of salted fish products and the number of businessmen are not inseparable from entrepreneurial behavior (Yuliana, 2012), while entrepreneurial behavior was one of the measurements to see the business performance of SMEs.

SMEs performance became an interesting issue because SMEs that has high performance would be able to face the competition expected to help the development and success of the business. To be able to know SMEs performance, it is necessary to identify its influencing factors, including external factors and internal factors that would show the entrepreneurial behavior, Lofian and Riyoko (2014). In line with the results of Rahmi's research (2016) which stated that individual factors, environmental factors and entrepreneurial behavior factors affected the business performance on plant and livestock integration systems.

According to Fritz Heider there are two sources of attribution to behavior; (1) internal attribution or dispositional attribution, and (2) external attribution or environmental attribution. The concept is also known as the "Causal Attribution" which is the explanation of the cause of a behavior, the internal causality is an attribute attached to the nature and personal or personal qualities, and external causality is present in the environment or situation (Mustafa, 2011). Therefore, to produce a good performance, the individual or businessmen must be able to know how to conduct the job well, and to know his desire as well as all the factors that affect his work (Griffin in Natipulu, 2000).

Based on the description, it is necessary to examine the influence of individual factors (psychological aspects of experience, confidence, motivation, skill, percentage of effort and effort) and environmental factors (availability of inputs, training support, capital assistance, promotional support, government support, and compactness of salted fish entrepreneurs) on the 
entrepreneurial behavior of salted fish businessmen and to analyze the influence of entrepreneurial behavior (diligent in trying, responsive to opportunities or able to innovate and dare to takerisks) and Business performance indicators (expansion of marketing, income increase, number of labor, competitive advantage and customer satisfaction) in salted fish businessmen at Muara Angke. It was conducted in order to find a sufficient approach in enhancing salted fish SMEs. It could also become a valuable information to the authority to determine a policy leading to entrepreneurial development in fishing sector, especially in this area.

The scope of this study is limited to the characteristics of salted fish businessmen in Muara Angke, individual and environmental factors, entrepreneurial behavior and performance of salted fish business, and the influence of individual and environmental factors on entrepreneurial behavior, and the influence of entrepreneurial behavior on business actors with the performance of salted fish business. This research was only conducted at salted fish SMEs in Muara Angke, DKI Jakarta Province; therefore, the result of this research is not applicable to the condition of other regions.

\section{METHODS}

This research was conducted in Muara Angke, North Jakarta, namely salted fish SMEs. Salted Fish SMEs in Muara Angke is the largest fish auction and fish processing in Jakarta. Determining the research location was done purposively by consideration that this location is the center of salted fish industry in Jakarta. This research was conducted from June to July 2017. The total number of the population in this research was 207 units of Salted fish SMEs in Muara Angke. The sample of this research used non probability sampling with purposive sampling method in Muara Angke. Purposive sampling method was used because the respondents were taken in accordance with the specific purpose of the researcher. The samples of this research were businessmen who processed many kinds of salted fish namely tuna, lethargy and stingray. Based on the criteria above, the researcher chose 120 businessmen as the samples of this research.

The type of data used of this research was primary and secondary data. Primary data were obtained by doing observation and interviewing the respondents using questionnaire scale 5 points likert. The secondary data were obtained from Maritime, Argiculture and Food security Office in Jakarta, Cooperative SMEs Office Region in Jakarta and Ministry of Maritime and Fisheries Affairs.

Data analysis used in this research was descriptive analysis and quantitative analysis. Quantitative data was processed by using SEM-PLS (Structural Equation Modeling-Partial Least Square) with Smart PLS 3.0 software that can explain the relationship between individual factors and environmental factors toward entrepreneurial behavior, and the relationship between entrepreneurial behaviour and business performance. PLS was also one of the variance-based Structural Equation Model (SEM) statistical methods designed to solve multiple regressions when data problems occur, such as small sample number, missing value, and multicolinearity (Abdillah \& Hartono, 2015). Hence, its method is an appropriate method to examine complex data obtained by researcher as well as to manage multicolinearity problems among independent variables. This method also can keep the robust results despite the data being abnormal and value missing. The main reason for using this method is to produce independent latent variables directly that is based on cross-production involving latent dependent variables as predictive forces and that can be used in reactive and formative constructs, which cannot be gained by other methods (Abdillah \& Hartono, 2015).

PLS model applied in this research was a reactive construct model whereas the usage of indicator was manifestation. The model consists of four latent variables, namely individual factor (X1), environmental factor (X2), entrepreneurial behavior (Y1), and business performance (Y2), whose first model will be analyzed through SMART PLS application version 3.0. The first step of evaluation was the initial improvement model that is based on the value of loading factor for each indicator. Indicators of each construction of this research will be issued gradually based on the smallest loading factor value until reaching the final result of the loading factor of each indicator $>0.5$ (Ghozali \& Latan, 2015). Furthermore, the result of the test would show some explanation of loading factor value, construct reliability and validity, discriminant validity, goodness of fit which would be used for final model test. 
In this study the standard loading factor used is $>0.5$. After performing the initial model improvement until the loading factor value of each indicator throughout the construct meets the standard, the model is re-estimated through the PLS Algorithm test. The evaluation of the model in PLS includes two stages, namely the outer model evaluation or the model of measurement and evaluation to the inner model or structural model. The variables used in this research consist of latent variables and indicator variables or manifest. The following were the identification and the references in the use of latent variables and indicator variables of this research. It can be seen in Table 1.

Table 1. Latent variabel and indicator variabel or manifest

\begin{tabular}{ll}
\hline $\begin{array}{l}\text { Latent } \\
\text { variabel }\end{array}$ & Indicator variabel/ manifest \\
\hline Individual & - Experience (X1.1) \\
factor & - Confidence (X1.2) \\
& - Motivation (X1.3) \\
& - Skills (X1.4) \\
& - Percentage of the business (X1.5) \\
& - Desire to business (X1.6) \\
Environment & - Readiness of raw material (X2.1) \\
factor & - Counseling and training (X2.2) \\
& - Venture capital (X2.3) \\
& - Government support (X2.4) \\
& - Cohesiveness between businessmen \\
& (X2.5) \\
Entrepreneurial & - Persistent (Y1.1) \\
behavior & - Creative (Y1.2) \\
& - Take a risk (Y1.4) \\
& - Innovative (Y1.3) \\
& - Independent (Y1.5) \\
Business & - Marketing expension (Y2.1) \\
performance & - Good marketing (Y2.2) \\
& - Competitive (Y2.3) \\
& - Customer Satisfaction (Y2.4) \\
\hline Source: &
\end{tabular}

Source: Dirlanuddin (2010), Puspitasari (2013), Sapar (2006).

\section{RESULTS}

\section{Result of Partial Least Square Analysis (PLS) Model of Measurement and Structural Model on Individual Factor, Environmental Factor, Entrepreneurial Behavior and Business Performance.}

The indication of the theoretical concepts which could not be measured or directly observed in theory and model in social sciences and behavior (social and behavioural sciences) could be found through SEM
(Wijanto, 2008). SEM-PLS can be used to explain the whole variables whether the relationship among variables exist or not.

The PLS model used in this research was a reflective model. This model has a relationship of four latent variables. Individual factor (X1) and environmental factor (X2) are an exogenous latent variable, while entrepreneurial behavior ( $\mathrm{Y} 1)$ and business performance (Y2) are endogenous latent variables.

\section{Outer Model (measurement model)}

This first step was evaluating the measurement model that is to make sure that the construct used in this research was valid and reliable. One factor which can be seen is the load factor or loading factor $(\lambda)$ with standard point 0.5 (Ghozali and Latan, 2015). Figure 1 below was a measurement model of the influence of individual factors, environmental factors, entrepreneurial behavior factor on salted fish business after respecification.

Nine rejected indicators on the initial PLS model results were issued so that the first requirements on the model had been fulfilled, then the data was reprocessed without an indicator already issued to obtain the best model. Based on the PLS results in Figure 1, then an indicator which has a value of loading above 0.5 could be obtained.

Through its method, individual factors (X1) in the final model are known to be reflected only by four indicators of self-confidence (X1.1), motivation (X1.3), skill (X1.4) and effort (X1.6). Individual variable of motivation indicator is a very big indicator able to explain individual factor that is equal to 0.772 , the most dominant individual factor reflected by motivation. Based on the results of the research in the field, it shows that salted fish business operators have high motivation in trying, one of which is shown by the motivation to strive to meet the needs of life in terms of finance both for families or themselves, to provide education for their children and to improve their social status. Motivation inherent in business actors to work a business is basically also supported by a high confidence. Indicators believe in individual factors of 0.702, according to Mateja et al. (2009) selfconfidence is one of the best predictor variables used for entrepreneurial studies; therefore, confidence is still quite capable in reflecting the individual factors. 
Environmental factors (X2) in the final model can only be reflected by two indicator variables namely government support (X2.4) and cohesiveness between business actors (X2.5). On environmental factors, government indicator support variable is the most dominant indicator in reflecting environmental factor that is equal to 0.882 . Government support indicator has high loading factor value because it is based on government assistance through land leasing that can be used to process salted fish with relatively cheap price already felt by salted fish businessmen. This government support in the form of land assistance is very useful for the community. Based on the research results of Okpa and Uche (2014) with the government's support for SME's based on the analysis result PLS able to create a conducive environment, in this case government support aims to regulate and improve the condition of SME's.

In latent variables entrepreneurial behavior dare to take risks is the most dominant indicator variable examining T-value in explaining entrepreneurial behavior with the loading factor value of 0.812 , meaning entrepreneurial behavior of salted fish business is more greatly represented by risk-taking indicator. This is in accordance with the results of Macko and Tyszka (2009) research in terms of entrepreneurship that finds a difference in the level of acceptance of risk between entrepreneurs and non-entrepreneurs; an entrepreneur is riskier than non-entrepreneur. The fact in the field also shows that all business actors in running the business can be said to be very brave to take risks, even though the salted fish processing business is a traditional business which still has significant risks in Indonesia.

The latent variable of business performance (Y2) in the final model can only be reflected by two indicator variables namely sales increase (Y2.2) and competitive advantage (Y2.3). In business performance, the most dominant indicator variable in explaining business performance is sales increase. Value loading factor increased sales by 0.879 , meaning that the increase in sales is very large in reflecting business performance. This indicates that the performance of salted fish business in Muara Angke is more represented by the increasing sales, although basically not all business actors are able to feel it because of various problems. However, the increase in sales has not been seen significantly but the salted fish products produced by business actors are always sold out. Some business actors can feel the increase in sales which has a large amount of production that can reach 10 tons per day and business actors who have side income so as to feel a significant increase in sales and profits. However, the research results of Rente (2010) showed that the increase of production, the increase of sales volume and profit processing less can push the increase of business unit from the SMEs of agribusiness in Papua province. This shows that the development of business units for SMEs agribusiness is a formidable challenge.

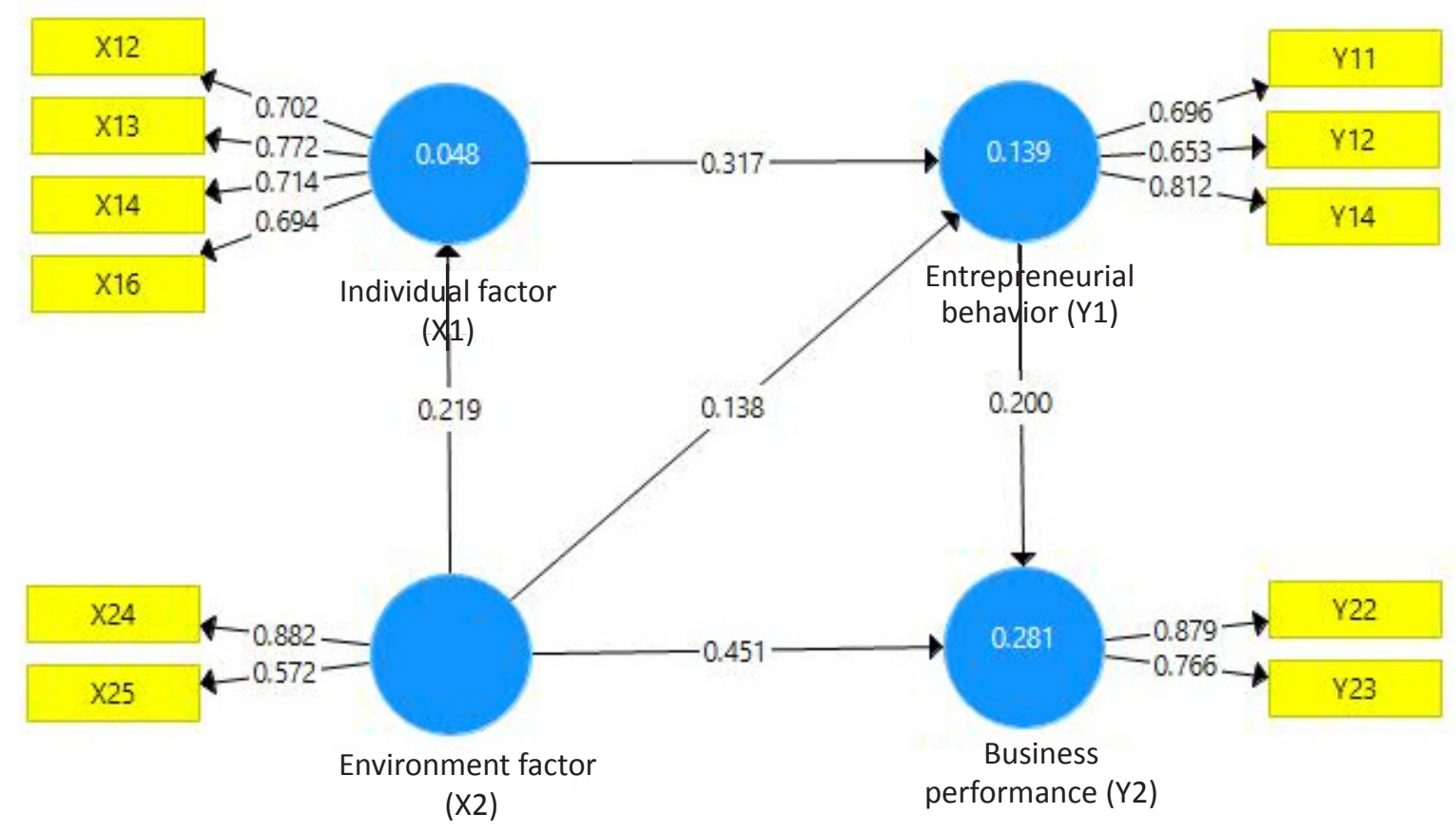

Figure 1. PLS Analysis 
Afterwards, looking the value of t-statistics, if the value was more than 1.96, it meant the model was fit (Figure 2). Based on the results of PLS bootstrapping, it was obtained with $t$ value greater than 1.96. The model of causal relationship between factors that influence entrepreneurial behavior and business performance of salted fish businessmen explain the influence between one latent variables and others is positive. The validity of the t-hitung value in Figure 2 also showed that the variable in the model was capable of measuring what should be measured or the model was able to explain the relationships between variables.

\section{Inner model (structural model)}

The second stage was evaluated structural model assessment to see the relationship between latent variables with its indicator. The result which was obtained could be seen from the estimation of path coefficients and significant levels. In this research, the structural model which was obtained could explain the influence of individual and environmental factors on entrepreneurial behavior as well as the influence between environmental factors and entrepreneurial behavior factors on business performance. On the other hand, by looking at the value of t-value, it is easy to know whether exogenous latent variables significantly influence endogen latent variables in this research model, and the amount of influence given. The significance value of the result of hypothesis test can be seen through result of bootstrapping which made in this research can be seen in Table 2 .

Based on Table 2, the results of hypothesis testing showed that individual factor had positive effect on the entrepreneurial behavior with t-value $3.860>1.96$ at the real level of 0.05 . It also occurred on the relationship of environmental factors. It also had positive effect and significant toward the individual factors on the real level of 0.05 with t-value $2.095>1.96$. Environmental factors also directly affected positively and significantly the business performance and entrepreneurial behavior immensely affected positively and significantly the business performance on the level of real 0.05 with t-tvalue $6.815>1.96$. However the environmental factors directly had positive effect, it had insignificant effect to entrepreneurial behavior. It meant that the level of entrepreneurship behavior of salted fish businessmen in Muara Angke was not influenced by environmental factors, but it was influenced by individual factors and significant to entrepreneurial behavior.

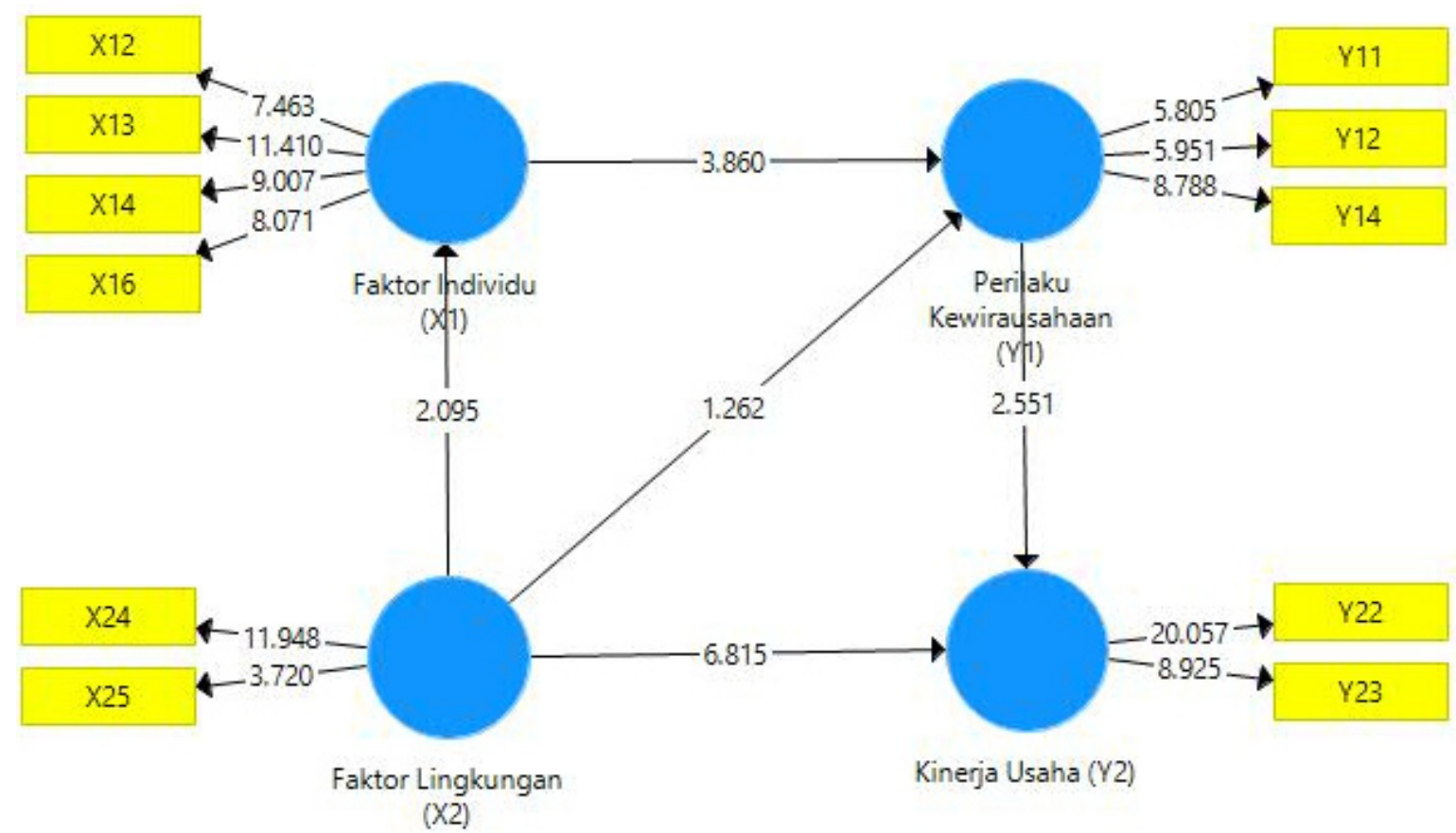

Figure 2. The result of $\mathrm{T}$ analysis 
Table 2. Evaluation of structural model coefficients

\begin{tabular}{llll}
\hline Variabel & Loading Factor & T-value & Note \\
\hline Individual factor $(\mathrm{X} 1) \rightarrow$ Entrepreneurial behavior (Y1) & 0.317 & 3.860 & Significant \\
Environmental factor (X2) $\rightarrow$ Individual factor (X1) & 0.219 & 2.095 & Significant \\
Environmental factor (X2) $\rightarrow$ Business performance (Y2) & 0.451 & 6.815 & Significant \\
Environmental factor (X2) $\rightarrow$ Entrepreneurial behavior (Y1) & 0.138 & 1.262 & Not significant \\
Entrepreneurial behavior (Y1) $\rightarrow$ Business performance (Y2) & 0.200 & 2.551 & Significant \\
\hline
\end{tabular}

Note: Significant when t-value $\geq 1.96$

\section{The Effect of Individual Factor and Environmental Factor on Entrepreneurial Behavior}

Other factors which influenced the entrepreneurial behavior of salted fish in Muara Angke are environmental factors. The result of bootstrapping estimation in the form of coefficient and t-statistic value for structural model (inner model) of PLS analysis was used to explain the relationship between exogenous latent and endogenous latent. The result of PLS analysis explained that in this research entrepreneurial behavior was influenced by individual factors of salted fish businessmen. It was explained by t-value which was greater than $t$ table $(3.860>1.96)$. In addition, the coefficient value had influence about 0.317 , which showed that the influential relationship of individual factors to entrepreneurial behavior was positive, where one percent increase of individual factors in salted fish businessmen would cause a 31.7 percent increase in entrepreneurial behavior of salted fish businessmen. Therefore, individual factors such as self-confidence, motivation, skill, and business desires could influence entrepreneurial behavior in Muara Angke. The most dominant indicator variable which reflected the individual factors of salted fish businessmen was motivation (X1.3). As research of Ijaz et al. (2012) found that family and friends took a strong role as a source to develop entrepreneurial behavior, moral and financial support that motivates businessmen to take risks in their business. The high motivation shown by business actors through persistence in trying to fulfill their life needs reflects a good motivation. Based on Kulkarni's (2015) research, the majority of business actors who have low economy possess high motivation. The existence of positive relation between businessmen motivation and entrepreneurship behavior cause the existence of expectation in business actors to continue. The work motivation to entrepreneurship behavior of salted fish business entrepreneur in Muara Angke has improved until finally has good impact on their business.
Confident business actors are built with confidence in running a salted fish processing business and confidence in determining job targets, so the higher the business confidence to determine work targets and gain profits, the higher the entrepreneurial behavior. Apart from this, the results of Petel's research (2014) showed that confidence (self-esteem) can explain the nature of individuals. The size of confidence is divided into three cathegories, low, medium and high. The confidence of dairy farmers is at a moderate level, meaning that dairy farmers have the ability to complete their duties and are able to face challenges. Confidence built by business actors certainly cannot be decided in a very short time, but business actors have been doing the learning process from other business actors both relatives and families who first run a business in order to increase confidence to run the business in the future with many profit targets .

Motivation, confidence and skills of salted fish businessmen could reflect the high effort of desires, so the level of desire to attempt the business of salted fish will have an impact on entrepreneurial behavior. In line with the research of Krishna (2012), it explained that the skills applied in the business will produce an effective entrepreneurship. The existence of a high effort to make salted fish business still survive until now in Muara Angke. Typically according to Wankhade's (2013) research, a desire to strive for success, management skill, confidence, knowledge, innovation and motivation has a significant effect on entrepreneurial behavior.

The result of PLS analysis explained that in this research the entrepreneurial behavior was not influenced by environmental factors. It was explained by t-value which was smaller than t-table $(1.262>1.96)$. The value of the coefficient influenced only 0.138 . This means that the influence given by environmental factors to entrepreneurial behavior was positive, but every one percent improvement of environmental factor in salted fish businessmen will only increase the 
entrepreneurship behavior 13.8 percent. On the other hand, the insignificant relationship indicated that the indicators on environmental factors such as government support and cohesiveness among businessmen could not affect the entrepreneurial behavior.

\section{The Effect of Entrepreneurship Behavior on Business Performance}

Based on the result of bootstrapping, it showed that the entrepreneurship behavior had positive and significant effect on business performance. It was seen from the value of t-statistics which was greater than 1.96 i.e. 2.551. This means that any increase in entrepreneurial behavior will improve business performance of salted fish business in Muara Angke. It can be explained that diligent in trying, creative and courage to take risks in running salted fish business will ultimately affect the improvement of business performance. As Rahmi's (2015) research revealed that entrepreneurial behavior had a direct and positive effect on business performance. The performance of a business depends on the actions (behavior) taken by the entrepreneur and the individual conditions that affect business decision making.

Entrepreneurial behavior in this research was reflected by three indicators namely diligent effort (Y1.1), creative (Y1.2) and dare to take risks (Y1.4). Based on the analysis of PLS indicators, it showed that dare to take a risk which is dominant risk in reflecting and explaining entrepreneurial behavior. The variable indicator "persistent" also reflected entrepreneurial behavior where businessmen had a commitment, high desire and seriousness on salted fish business. It was seen through strong determination of businessmen to continue working on salted fish business even though the income has not been relevant with the expectations of the businessmen. The indicator "creative" on salted fish businessmen was considered still low, based on the loading value which was low. It was because the reality of the field was merely small businessmen who were able to take advantage of opportunities to think creatively for the development of their products. In addition, businessmen were also still reluctant to attend various exhibition events to promote their products. According to Munandar and Utami (2009), creativity and innovation need to be developed because with creativity and innovative someone can improve the self-realization, by thinking creative and innovative. It could also solve the problems with logical mind, giving individual satisfaction because it could provide benefits for themselves and environment (entrepreneur). By thinking creatively someone can improve the quality of his life.

\section{Managerial Implication}

The managerial implication is intended for local governments through the offices / agencies in charge of controlling and maintaining salted fish businesses in Muara Angke in order to sustainably continue doing business development. Based on the results of this study, the individual factors of salted fish businesses that involve the level of confidence, motivation of business actors in business, skills and business desire, in fact have been sufficient enough to become a strong foundation for the development of salted fish processing business. In order to improve the welfare of the perpetrators of salted fish businesses in Muara Angke, it is recommended that agencies continue to provide training or guidance to optimally improve technical capabilities and open the mind of business people to become entrepreneurs who have other skills related to processed fish products that are in line with consumer taste.

The results of this study also prove that entrepreneurial behavior has a positive and significant effect on business performance; thus the potential ability of business actors needs to be maximized, especially at the level of creativity, because in reality, the success of business actors in achieving high business performance is not only determined by the processing, but also by the ability of the business actor on the actualized attitudes, knowledge and skills to produce creativity in running the business starting from the process of selecting raw materials to marketing the products produced. One of the entrepreneurial behaviors that are important in business development is the behavior of creativity, because with the attitude of creativity in the business actor, it will be able to produce new ideas that are the source of new innovations to meet the growing needs of the market. Business practitioners' creativity can be sharpened by participating in various promotional and exhibition events and having discussions with other business actors who are more successful and experienced. 


\section{CONCLUSIONS AND RECOMMENDATIONS}

\section{Conclusions}

Based on the result of this research, Individual factor was positive and significant to entrepreneurial behavior with the most dominant indicator is motivation $(\lambda)$ equal to 0.772 . This showed that individual factors in the form of self-confidence, motivation, skill, and high effort desire can improve entrepreneurial behavior. Apart from this, environmental factor had positive and significant influence on individual factors, whereas environmental factor also had positive and significant influence on enterpreneurial performance with the most dominant indicator (0.672). Although environmental factors had positive effects on entrepreneurship behavior, it was insignificant because the government support in the form of capital aid, extension support and training, and the availability of market information is insufficient with the needs of salted fish business and is considered not on target. Additionally, enterpreunership behavior factor was significant and positive to business performance with the most dominant indicator compare the risk $(\lambda)$ equal to 0.812 . The latent variables of Entrepreneurship Behavior had a positive and significant impact on Business Performance. This revealed that entrepreneurial behavior played an important role in improving business performance. Thus, with perseverance in trying, creative and courage to take risks, it will affect business performance in the future. Consequently, it will lead the progression of fishing industry to a brighter establishment if it is supported by the government aid.

\section{Recommendations}

Recommendations from this research are directed to local government through offices or related agencies in charge of controlling and fostering salted fish businessmen in Muara Angke in order to support them. According to the research, individual factors had a positive and significant impact on entrepreneurial behavior. It can be said that the individual factors of salted fish business entrepreneurs, concerning the level of confidence, the motivation of business actors in the effort, the skill and the desire to try, have been sufficient to be a strong reason for the government to develop salted fish processing business, by providing intensive training or guidance to improve technical skills and to open the minds of business actors being entrepreneurs who have other skills related to the processed products of fish that suit the development of consumer tastes. Thus, the businessmen can be encouraged to look for a newly enhancement of technology and to be willing to be the first person in conducting a new inovation related to fish processing business. It is expected that in the end, the business performance and the prosperity of salted fish businessmen in Muara Angke will be improved.

\section{REFERENCES}

Abdillah W, Hartono J. 2015. Partial Least Square PLS. Yogyakarta: Andi.

Chang,YC, Ming HC, Phil YY. 2009. Factors Influencing Academic Entrepreneurship: The Case of Taiwan, Yuan-Ze University and National Chi Nan University, Taiwan.

Dirlanudin. 2010. Perilaku wirausaha dan keberdayaan pengusaha kecil industri agro: kasus di Kabupaten Serang Provinsi Banten [dissertation].Bogor: Institut Pertanian Bogor.

Ghozali I, Latan H. 2014. Partial Least Square. Konsep, Teknik dan Aplikasi Menggunakan Program SmartPLS 3.0. Semarang: Universitas Diponegoro.

Ijaz M, Yasin G, Zafar MJ. 2012. Cultural factors effecting enterpreneurial behaviour among enterpreneurship. Case study of multan, pakistan. International Journal of Asian Social Science 2(6): 908-917.

[KKP] Kementrian Kelautan dan Perikanan. 2013. Perikanan budidaya Indonesia. http://djpb.kkp. go.id [10 April 2018].

Krishna MM, Annie T, Caroline C, Chang SW, Jonathan TYP, Tan KL. 2012. A Study on Factors Affecting the Performance of SMEs in Malaysia. International Journal of Academic Research in Business and Social Sciences 2(4).

Lofian B, Riyoko S. 2014. Identifikasi faktor eksternal dan faktor internal yang berpengaruh terhadap kinerja ukm mebel rotan di Jepara. Jurnal DISPROTEK 5(2).

Macko A, Tyszka T. 2009. Entrepreneurship and Risk Taking. An international assosiation of applied phsycology 58(3): 469-487. https://doi. org/10.1111/j.1464-0597.2009.00402.x.

Mateja et al. 2009. Entrepreneurial self-efficacy and business start-up: developing a multi- 
dimensional definition. International Journal of Entrepreneurial Behaviour \& Research 16(4): 329-348.

Munandar, Utami.2009. Pengembangan Kreativitas Anak Berbakat. Jakarta: PT. Penerbit Rineka Cipta.

Mustafa H. 2011. Perilaku Manusia dalam Perspektif Psikologi Sosial. Jurnal Administrasi Bisnis 7(2): 143-156.

Okpa NO, Uche MO. 2014. The role of government policy in entrepreneurship development. Science Journal of Business and Management 24: 109115.

Patel P, Patel MM, Badodia SK, Sharma P. 2014. Entrepreneurial behaviour of dairy farmers. Indian Research Journal of Extension Education 14 (2): 46-49.

Puspitasari. 2015. Pengaruh perilaku kewirausahaan petani anggrek terhadap kinerja usaha [thesis]. Bogor: Institut Pertanian Bogor.

Rahmi. 2015. Pengaruh perilaku kewirausahaan terhadap kinerja usaha pada sistem integrasi tanaman dan ternak [Tesis]. Bogor: Institut Pertanian Bogor.
Rente Y. 2010. Pengaruh Budaya Etnis dan Perilaku Kewirausahaan Terhadap Kinerja Usaha Mikro Kecil Agribisnis. Jurnal Manajemen dan Kewirausahaan 12(2): 133-141.

Sapar. 2006. Faktor-faktor yang berhubungan dengan perilaku kewirausahaan pedagang kaki lima [thesis].Bogor: Institut Pertanian Bogor.

Tajerin M, Sastrawidjaja. 2010. Dinamika Keterkaitan Sektor Kelautan dan Perikanan dalam Perekonomian Indonesia 1995-2005: Pendekatan Rasmussen's Dual Criterion. Jurnal Kebijakan dan Riset Sosek Kelautan dan Perikanan 5(1): 97-112. https://doi.org/10.15578/jsekp. v5i1.5794.

Wijanto SH. 2008. Structural Equation Modelling dengan Lisrel 8.8: Konsep dan Tutorial. Yogyakarta: Graha Ilmu.

Wankhade RP, Sagane MA, Mankar DM. 2013. Entrepreneurial behaviour of vegetable growers agricultural research communication centre. Agricultural Science Digest 33(2):85-91.

Yuliana E. 2012. Sikap pengolah dalam menentukan produk ikan asin. Jurnal Pengolahan Hasil Perikanan Indonesia 15(1):1-8. 